Article

\title{
Treatment of Landfill Leachate Using Palm Oil Mill Effluent
}

\author{
Tawfiq J. H. Banch ${ }^{1}$, Marlia M. Hanafiah ${ }^{1,2, *}$, Salem S. Abu Amr ${ }^{3}$, Abbas F. M. Alkarkhi ${ }^{3}$ and \\ Mohammed Hasan ${ }^{1}$ \\ 1 Department of Earth Sciences and Environment, Faculty of Science and Technology, Universiti Kebangsaan \\ Malaysia, Bangi 43600, Selangor, Malaysia; banch4@gmail.com (T.J.H.B.); aldulaimi89_fst@yahoo.com (M.H.) \\ 2 Centre for Tropical Climate Change System, Institute of Climate Change, Universiti Kebangsaan Malaysia, \\ Bangi 43600, Selangor, Malaysia \\ 3 Universiti Kuala Lumpur Business School (Unikl bis), Kuala Lumpur 50250, Malaysia; \\ sabuamr@hotmail.com (S.S.A.A.); alkarkhii@gmail.com (A.F.M.A.) \\ * Correspondence: mhmarlia@ukm.edu.my
}

Received: 18 April 2020; Accepted: 14 May 2020; Published: 18 May 2020

check for updates

\begin{abstract}
Sanitary landfilling is the most common method of removing urban solid waste in developing countries. Landfills contain high levels of organic materials, ammonia, and heavy metals, thereby producing leachate which causes a possible future pollution of ground and surface water. Recently, agricultural waste was considered a co-substratum to promote the biodegradation of organics in industrial wastewater. The use of low-cost and natural materials for wastewater treatment is now being considered by many researchers. In this study, palm oil mill effluent (POME) was used for treating stabilized leachate from old landfill. A set of preliminary experiments using different POME/leachate ratios and aeration times was performed to identify the setting of experimental design and optimize the effect of employing POME on four responses: chemical oxygen demand (COD), total suspended solids (TSS), color, and ammoniacal nitrogen $\left(\mathrm{NH}_{3}-\mathrm{N}\right)$. The treatment efficiency was evaluated based on the removal of four selected (responses) parameters. The optimum removal efficiency for COD, TSS, color, and $\mathrm{NH}_{3}-\mathrm{N}$ was $87.15 \%, 65.54 \%, 52.78 \%$, and $91.75 \%$, respectively, using a POME/leachate mixing ratio of $188.32 \mathrm{~mL} / 811.68 \mathrm{~mL}$ and 21 days of aeration time. The results demonstrate that POME-based agricultural waste can be effectively employed for organic removal from leachate.
\end{abstract}

Keywords: landfill; leachate treatment; POME; removal efficiency; mixing ratio

\section{Introduction}

The landfilling of solid waste is still a significant problem in the solid waste management systems of all countries worldwide [1,2]. However, landfill leachate is a complex liquid generated from rainwater penetration through landfills that often includes high-strength contaminant resistance, such as humic acids, ammonia nitrogen, heavy metals, xenobiotics, and inorganic salts, which are important to avoid due to their adverse effects on the environment $[3,4]$. The factors that affect the composition of landfill leachate include the composition of waste, the level of compaction, the absorptive capacity of solid waste and age of solid waste, weather variations, precipitation, landfilling temperature, size of landfilling, hydrogeological conditions, factors of the landfill operation, $\mathrm{pH}$, and chemical and biological activities in the process of landfilling [5,6]. In general, young leachate produced from new landfills ( $<5$ years old) has a large biodegradation of comparatively low-molecular-weight materials, such as volatile organic acids, chemical oxygen demand (COD), total organic carbon (TOC), biological oxygen demand $\left(\mathrm{BOD}_{5}\right)$, and biodegradability $\left(\mathrm{BOD}_{5} / \mathrm{COD}\right)$ [7]. On the other hand, old leachate (>10 years old) has high organic content of relatively high-molecular-weight materials, for instance, 
humic and fulvic substances that are refractory and not rapidly degradable. Generally, old leachate has a lower concentration of $\mathrm{COD}, \mathrm{TOC}, \mathrm{BOD}_{5}$, and $\mathrm{BOD}_{5} / \mathrm{COD}[6,7]$. Leachate is stabilized and has low biodegradability since most landfills are old [8-11]. As a landfill gets older, a change from a relatively shorter initial aerobic to a longer anaerobic decomposition period takes place. Due to the biological breakdown of organic compounds and precipitation of soluble components, such as heavy metals, the strength of leachate generally lowers over time. Because of its biodegradable nature, organic compounds decrease faster than inorganic compounds with the increasing age of leachate production.

Several treatment techniques, such as physico-chemical processes, are used to treat leachate (coagulation precipitation, activated carbon adsorption [12,13], membrane filtration, activated carbon adsorption [14,15], and/or other separation techniques) [16], in addition to biological treatment methods, such as aerobic and anaerobic processes. In the past two decades, many studies reported that biological processes in the treatment of young leachate are effective but are comparatively insufficient in the treatment of old leachate because of the existence of bio-refractory substances [6,7]. Currently used procedures often involve mixed methods intended as modular or multi-stage units that are capable of treating pollutants that change in concentration over time. The appropriate treatment of leachate is applied to enhance and develop an appropriate technique of treatment that meets the relevant quality standards and regulations [5].

In particular, the palm oil sector in Malaysia adopts four types of treatment technologies: waste stabilization ponds, activated sludge systems, closed anaerobic digesters, and land application systems [17]. However, many questions remain unanswered about the cost of treatment, the production of sludge, and chemical residues in treated wastewater. Usage of low-cost and natural materials of wastewater treatment are currently gaining increased attention from a series of studies. Palm oil mill effluent (POME) is classified as a pollutant which is known for its ability to enhance the biodegradability of pollutants due to the relatively high content of organic matter $[18,19]$. An aeration process supplies the oxygen to the wastewater and acts as an oxidation of organics. Moreover, oxygen can also enhance the biodegradation of organics by bacteria which use oxygen to break down the organic matter into the form of $\mathrm{CO}_{2}$ and $\mathrm{H}_{2} \mathrm{O}$ [20]. Stripping of ammonia is a simple desorption method utilized to reduce the ammonia concentration of leachate. Ammonia reacts with water to form ammonium hydroxide [21], as shown in Equation (1).

$$
\mathrm{NH}_{4}{ }^{+}+\mathrm{OH}^{-*} \leftrightarrow \mathrm{H}_{2} \mathrm{O}+\mathrm{NH}_{3}{ }^{*} .
$$

The alkaline wastewater flows downward when the air enters through the bottle. As the air continues to flow, the wastewater moves in the opposite direction and ascends to the top of the aeration bottle. $\mathrm{NH}_{3}$ is stripped from dropping water droplets into the air flow, and then released into the atmosphere [22]. In this research, the effectiveness of aeration processes used in the treatment of a leachate/POME mixture was evaluated. The optimum experimental conditions for POME dosages were designed, and the ability to remove the different medicines was studied. In addition, the efficacy of POME in the leachate removal of heavy metals was also investigated. The removal of heavy metals by POME during aeration may be attributed to the high level of suspended solids in POME, which may act as a natural coagulant [23].

\section{Methodology}

\subsection{Collection of the Samples and Landfill Characteristics}

Samples of leachate were sampled from the Ampar Tenang Closed Landfill Site (ATCL). ATCL is situated nearly $40 \mathrm{~km}$ southwest of Kuala Lumpur, Malaysia at a latitude of $02^{\circ} 48.9250$ north (N) and a longitude of $101^{\circ} 4.9330$ east (E) [23]. ATCL is mostly surrounded by oil palm plantations. Labu River flows along the landfill $300 \mathrm{~m}$ away. The ATCL area is characterized as tropical. The average temperature is $27.2^{\circ} \mathrm{C}$, and the average rainfall is $2287 \mathrm{~mm} /$ year [24]. The landfill site is located on the eastern sector of the confined alluvial aquifer of the Langat Basin, composed primarily of silt $(50 \%-70 \%)$, clay $(<25 \%)$, and sand $(<25 \%)$ [25-27]. This site is more clayey close to the surface of 
the ground, but changes to sandy in lower layers [25,26]. ATCL operated as of 1994 for a total of 15 years. About 100 tons of waste are dumped into this site every day during the operation of the landfill. This results in the on-site disposal of a total of half a million tons of solid waste. The site was completely closed in 2010. Before it was closed, it was converted to sanitary classification (Level 1) from a disposal site (Level 0) $[8,27,28]$. In 2018, the samples were manually collected and placed in 1000-mL containers manufactured from polyethylene. The samples were collected at $4{ }^{\circ} \mathrm{C}$ and immediately transformed to prevent significant biological degradation and chemical reactions. The samples were transported in a preservation refrigerator from the site to the laboratory before being stored in the laboratory refrigerator until the next day where the experiment was prepared; no acids were used for preservation.

\subsection{Leachate and POME Characterizations}

The physico-chemical characterization of the leachate is presented in Table 1.

Table 1. Physico-chemical characteristics and heavy metals of leachate.

\begin{tabular}{ccc}
\hline Parameter & Mean and Standard Deviation & USEPA $^{*}$. DOE \\
**) \\
\hline $\mathrm{pH}$ & $7.88 \pm 0.50$ & $6-9^{* *}$ \\
$\mathrm{EC}(\mu \mathrm{S} / \mathrm{cm})$ & $6565 \pm 324$ & $1400^{*}$ \\
$\mathrm{TDS}(\mathrm{mg} / \mathrm{L})$ & $4671 \pm 174$ & $1000^{*}$ \\
$\mathrm{TSS}(\mathrm{mg} / \mathrm{L})$ & $40.45 \pm 8$ & $50^{* *}$ \\
$\mathrm{COD}(\mathrm{mg} / \mathrm{L})$ & $893.41 \pm 202$ & $400^{* *}$ \\
$\mathrm{BOD}(\mathrm{mg} / \mathrm{L})$ & $59.20 \pm 10$ & $20^{* *}$ \\
$\mathrm{NH}_{3}-\mathrm{N}(\mathrm{mg} / \mathrm{L})$ & $530.7 \pm 22$ & $5^{* *}$ \\
$\mathrm{DO}(\mathrm{mg} / \mathrm{L})$ & $5.43 \pm 2$ & $5^{*}$ \\
$\mathrm{Mg}^{2+}(\mathrm{mg} / \mathrm{L})$ & $19.72 \pm 4$ & $0.2^{*}$ \\
$\mathrm{Ca}^{2+}(\mathrm{mg} / \mathrm{L})$ & $39.72 \pm 34$ & $0.1^{*}$ \\
$\mathrm{Na}^{+}(\mathrm{mg} / \mathrm{L})$ & $638.80 \pm 303$ & $0.02^{* *}$ \\
$\mathrm{Fe}^{2+}(\mathrm{mg} / \mathrm{L})$ & $0.78 \pm 0.6$ & $5^{* *}$ \\
$\mathrm{Zn}^{2+}(\mu \mathrm{g} / \mathrm{L})$ & $280 \pm 16$ & $2^{* *}$ \\
$\mathrm{Cu}^{2+}(\mu \mathrm{g} / \mathrm{L})$ & $41.87 \pm 24$ & $0.2^{* *}$ \\
$\mathrm{Cr}^{2+}(\mu \mathrm{g} / \mathrm{L})$ & $45.11 \pm 17$ & $0.01^{* *}$ \\
$\mathrm{Cd}^{2+}(\mu \mathrm{g} / \mathrm{L})$ & $0.62 \pm 0.7$ & $0.01^{* *}$ \\
$\mathrm{~Pb}^{+}(\mu \mathrm{g} / \mathrm{L})$ & $4.18 \pm 2.7$ & $0.01^{* *}$ \\
$\mathrm{As}^{3+}(\mu \mathrm{g} / \mathrm{L})$ & $17.3 \pm 7$ & $0.05^{* *}$ \\
$\mathrm{Co}^{2+}(\mu \mathrm{g} / \mathrm{L})$ & $11.05 \pm 8$ & $0.05^{*}$ \\
$\mathrm{Mn}^{2+}(\mu \mathrm{g} / \mathrm{L})$ & $61.40 \pm 49$ & $0.02^{* *}$
\end{tabular}

* [29], ** [30]. Abbreviation. EC: electrical conductivity; TDS: total dissolved solids; TSS: total suspended solids; COD: chemical oxygen demand; $\mathrm{BOD}_{5}$ : biochemical oxygen demand; $\mathrm{NH}_{3}-\mathrm{N}$ : ammoniacal nitrogen; $\mathrm{DO}$ : dissolved oxygen; USEPA: U.S. Environmental Protection Agency; DOE: Department of Environment.

The physico-chemical characterization of the POME is presented in Table 2.

Table 2. Physico-chemical characteristics and heavy metals of palm oil mill effluent (POME).

\begin{tabular}{ccc}
\hline Parameter & Mean and Standard Deviation & (Standard of DOE *) \\
\hline $\mathrm{pH}$ & $4.40 \pm 0.01$ & $5.0-9.0$ \\
$\mathrm{EC}(\mu \mathrm{S} / \mathrm{cm})$ & $8553 \pm 114$ & 100 \\
Salinity $(\mathrm{ppt})$ & $4.9 \pm 0$ & $\mathrm{NA}$ \\
$\mathrm{TDS}(\mathrm{mg} / \mathrm{L})$ & $5713 \pm 15$ & $\mathrm{NA}$ \\
$\mathrm{TSS}(\mathrm{mg} / \mathrm{L})$ & $3483 \pm 76$ & 200 \\
Color $(\mathrm{Pt} / \mathrm{Co})$ & $5517 \pm 104$ & 100 \\
$\mathrm{COD}(\mathrm{mg} / \mathrm{L})$ & $17,400 \pm 100$ & $\mathrm{NA}$ \\
$\mathrm{BOD}_{5}(\mathrm{mg} / \mathrm{L})$ & $1243 \pm 51$ & $\mathrm{NA}$ \\
$\mathrm{BOD}_{5} / \mathrm{COD}$ & $0.07 \pm 0$ & $\mathrm{NA}$ \\
\hline
\end{tabular}


Table 2. Cont.

\begin{tabular}{ccc}
\hline Parameter & Mean and Standard Deviation & (Standard of DOE *) \\
\hline $\mathrm{NH}_{3}-\mathrm{N}(\mathrm{mg} / \mathrm{L})$ & $308 \pm 58$ & $\mathrm{NA}$ \\
$\mathrm{DO}(\mathrm{mg} / \mathrm{L})$ & $6.74 \pm 0.05$ & $\mathrm{NA}$ \\
$\mathrm{Mg}^{2+}(\mathrm{mg} / \mathrm{L})$ & $285 \pm 5$ & $\mathrm{NA}$ \\
$\mathrm{Ca}^{2+}(\mathrm{mg} / \mathrm{L})$ & $47.34 \pm 0.03$ & $\mathrm{NA}$ \\
$\mathrm{Fe}^{2+}(\mathrm{mg} / \mathrm{L})$ & $45.31 \pm 0.9$ & 50 \\
$\mathrm{Zn}^{2+}(\mu \mathrm{g} / \mathrm{L})$ & $2603 \pm 5.77$ & 10 \\
$\mathrm{Cu}^{2+}(\mu \mathrm{g} / \mathrm{L})$ & $2130.00 \pm 26.46$ & 10 \\
$\mathrm{Cr}^{2+}(\mu \mathrm{g} / \mathrm{L})$ & $910.00 \pm 10$ & $\mathrm{NA}$ \\
$\mathrm{Cd}^{2+}(\mu \mathrm{g} / \mathrm{L})$ & $\mathrm{NA}$ \\
$\mathrm{Pb}^{+}(\mu \mathrm{g} / \mathrm{L})$ & $\mathrm{NA}$ \\
$\mathrm{As}^{3+}(\mu \mathrm{g} / \mathrm{L})$ & $50.10 \pm 0.03$ & $\mathrm{NA}$ \\
$\mathrm{Co}^{2+}(\mu \mathrm{g} / \mathrm{L})$ & $100.22 \pm 0.44$ & $\mathrm{NA}$ \\
$\mathrm{Mn}^{2+}(\mu \mathrm{g} / \mathrm{L})$ & $41.08 \pm 0.17$ & 10 \\
\hline
\end{tabular}

\subsection{Experimental Procedure}

A bubble column bioreactor was used for the aeration process. It is characterized by its simple construction, higher efficiency in removal, and efficient control of the liquid residence time [31]. The aeration process was conducted at room temperature $\left(25^{\circ} \mathrm{C}\right)$. In the aeration process, the air pump is connected to four bottles of one liter each by a tube of $1 \mathrm{~mm}$ in diameter; these bottles contain different ratios of leachate/POME, and the process continues for 21 days.

The experiment was conducted in two steps; the first step was a preliminary experiment performed utilizing one factor at a time to determine the area of concern for each influential variable of the leachate/POME ratio and the aeration time to determine the optimal levels. The selected levels for the leachate/POME ratio and the aeration time were utilized to conduct the second step utilizing response surface methodology (RSM). RSM consists of a group of experimental methods devoted to estimating the relationship between a group of experimental variables (factors) and the (targeted) measured responses. To build a more practical model, the process variables under investigation need to be understood. Central composite face-centered (CCF), a type of central composite design (CCD), was used for two independent variables to estimate the effect value of POME dosages and aeration time on four response variables: COD, TSS, color, and $\mathrm{NH}_{3}-\mathrm{N}$.

\subsection{Effect of the Leachate/POME Ratio}

For the first step, POME was used to improve the biodegradation of leachate. In $1000 \mathrm{~mL}$ of leachate samples, different leachate/POME ratios (1:0, 0.9:0.1, 0.7:0.3, and 0.5:0.50) were used. The initial $\mathrm{pH}$ for the leachate sample (8.4) was left unadjusted. The liquid was aerated using an aeration bump (HAILEA) model V-20 with output $20 \mathrm{~L} / \mathrm{min}$ and pressure $>0.02 \mathrm{MPa}$ for 24 days. The treatment efficiency was evaluated based on $\mathrm{COD}$, TSS, color, and $\mathrm{NH}_{3}-\mathrm{N}$ removal efficiency.

The efficiency for COD removal was estimated using Equation (2).

$$
\text { COD Removal }(\%)=\left[\left(C_{r}-C_{k}\right) / C_{i}\right] \times 100,
$$

where $C_{r}$ is the initial COD concentration, and $C_{k}$ is the final COD concentration.

\subsection{Optimization of Treatment Efficiencies of Targeted Parameters}

Using Design-Expert software (version 6.0.7), a central composite design (CCD) for the leachate/POME ratio was developed to examine whether COD, TSS, color, and $\mathrm{NH}_{3}-\mathrm{N}$ affected the leachate/POME ratio and aeration time. Depending on the preliminary experiments stated in Section 2.3, the amounts and rates of each factor were chosen. Thirteen experiments were conducted to include all possible combinations of the leachate/POME ratio and aeration time. 
Data from different CCD experiments were utilized to appropriate a polynomial model and a second-order model (Equation (3)).

$$
Y=\beta_{0}+\sum_{j=1}^{k} \beta_{j} X_{j}+\sum_{j=1}^{k} \beta_{j j} x^{2}+\sum_{i} \sum_{<j=2}^{k} \beta_{i j} X_{i} X_{j}+e_{i}^{\prime}
$$

where $Y$ is the response, $X_{i}$ and $X_{j}$ are the variables, $\beta$ is the regression coefficient, $k$ is the number of variables tested and optimized in this experiment, and e is the random error. A $p$-value less than 0.05 was reported as significant.

\section{Analytical Work}

The chemical oxygen demand (COD), $\mathrm{pH}$, biochemical oxygen demand $\left(\mathrm{BOD}_{5}\right)$, electrical conductivity (EC), total suspended solids (TSS), ammoniacal nitrogen $\left(\mathrm{NH}_{3}-\mathrm{N}\right)$, and heavy metals (magnesium $\left(\mathrm{Mg}^{2+}\right)$, calcium $\left(\mathrm{Ca}^{2+}\right)$, iron $\left(\mathrm{Fe}^{2+}\right)$, zinc $\left(\mathrm{Zn}^{2+}\right)$, copper $\left(\mathrm{Cu}^{2+}\right)$, chromium $\left(\mathrm{Cr}^{2+}\right)$, cadmium $\left(\mathrm{Cd}^{2+}\right)$, lead $\left(\mathrm{Pb}^{2+}\right)$, arsenic $\left(\mathrm{As}^{3+}\right)$, cobalt $\left(\mathrm{Co}^{2+}\right)$, and manganese $\left(\mathrm{Mn}^{2+}\right)$ ) were tested before and after each aeration run. The level of $\mathrm{BOD}_{5}$ was estimated utilizing Method 5210B. The DO was tested utilizing a DO meter (model 1000, YSI Inc., Greene County, OH, USA). COD concentration was tested utilizing the closed reflux colorimetric method (5220B-DR2500 HACH, Loveland, CO, USA). Color was determined using the DR $2800 \mathrm{HACH}$ spectrophotometer at $455 \mathrm{~nm}$ wavelength.

A portable digital $\mathrm{pH} / \mathrm{mV}$ meter (model inoLab $\mathrm{pH} 720$, WTW, Weilheim, Germany) was used to measure the $\mathrm{pH}$ and EC. TSS was determined utilizing method $2540 \mathrm{D}$, dried at $103-105{ }^{\circ} \mathrm{C}$, which included the following procedure: preparation of filter disc, selection of filter type and sample volume, analysis of samples, and calculation of Equation (4) (APHA 2012) [31].

$$
\text { TSS } m g / L=[(A-B) m g /(V) m L,
$$

where $\mathrm{A}$ is the weight of filter-dried residue $(\mathrm{mg}), \mathrm{B}$ is the weight of the filter, and $\mathrm{V}$ is the sample volume.

$\mathrm{NH}_{3}-\mathrm{N}$ level was determined using the phenate method $\left(4500-\mathrm{NH}_{3} \mathrm{~F}\right)$ utilizing a DR2500 spectrophotometer at $640 \mathrm{~nm}$. Heavy metals were measured using atomic absorption spectroscopy (Unicam 929 AA Spectrophotometer, UNICO, Franksville, WI, USA). All physico-chemical parameters and heavy metals were measured according to standard methods for examining water and wastewater [32]. Different leachate/POME ratios (1:0, 0.9:0.1, 0.7:0.3, and 0.5:0.50) were prepared in 1000 -mL bottles to investigate the removal efficiency of targeted parameters.

\section{Results and Discussion}

\subsection{Effects of Aeration Time Variation on the Removal Efficiency during the Aeration Process of Leachate Treatment}

The maximum removal efficiencies in only leachate aeration for COD, TSS, color, and $\mathrm{NH}_{3}-\mathrm{N}$ reached $44.12 \%, 43.5 \%, 55 \%$, and $97 \%$. Figure 1 shows the removal efficiency influenced by the time of reaction for the targeted parameters. The removal efficiencies of both COD and TSS increased slightly in the same way. However, the increased color removal efficiency was characterized by fluctuation, as shown on Figure 1, while the removal efficiency of $\mathrm{NH}_{3}-\mathrm{N}$ increased sharply in the first week of aeration, reaching $93 \%$ on the seventh day; it did not demonstrate a further marked increase in removal efficiency, reaching $97 \%$ by the 24 th day. This is in line with many studies reporting that $\mathrm{NH}_{3}-\mathrm{N}_{\text {can }}$ be removed under the effect of the gas stripping process during aeration [21], while the removal is significantly improved with aeration time increasing up to a specific point [33] due to the reaction of $\mathrm{NH}_{3}$ with water, as shown in Equation (5).

$$
\mathrm{NH}_{3}+\mathrm{H}_{2} \mathrm{O} \leftrightarrow \mathrm{NH}_{4}^{+}+\mathrm{OH}^{-}
$$


From Equation (5), increasing the $\mathrm{pH}$ due to the formation of $\mathrm{OH}^{-}$will increase the concentration of $\mathrm{NH}_{3}$. The increase in $\mathrm{pH}$ enhances the ammonia stripping during aeration [21] and enhances the removal of ammonia, after which, owing to the recarbonation of lime in leachate, the $\mathrm{pH}$ begins to decline by absorbing $\mathrm{CO}_{2}$ from the ambient air [34].

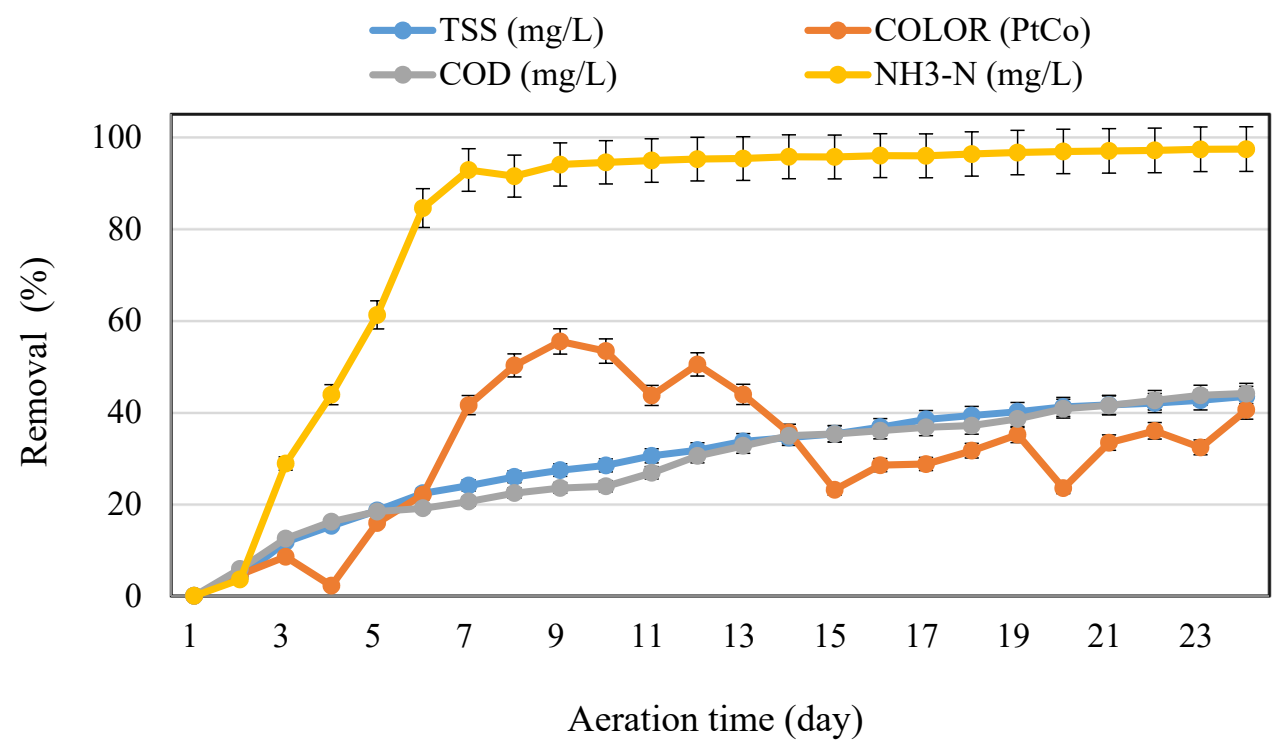

Figure 1. Effects of reaction time variation on COD, TSS, color, and $\mathrm{NH}_{3}-\mathrm{N}$ removal efficiency (with natural $\mathrm{pH}$, leachate only, aeration $20 \mathrm{~L} / \mathrm{min}$ ).

3.2. Effects of Reaction Time Variation on the Removal Efficiency during the Aeration Time of Leachate/POME Treatment (Ratio $900 \mathrm{~mL}$ Leachate/100 mL POME)

In this stage, the effect of the reaction time on leachate with a ratio of $900 \mathrm{~mL}$ leachate/100 $\mathrm{mL}$ POME was investigated during the aeration time. The optimum reaction time was reached on the 24th day of aeration, and the maximum removal efficiencies for COD, TSS, color, and $\mathrm{NH}_{3}-\mathrm{N}$ reached $91 \%, 54 \%, 50 \%$, and $98 \%$, respectively. All targeted parameters increased as the aeration time increased (Figure 2).

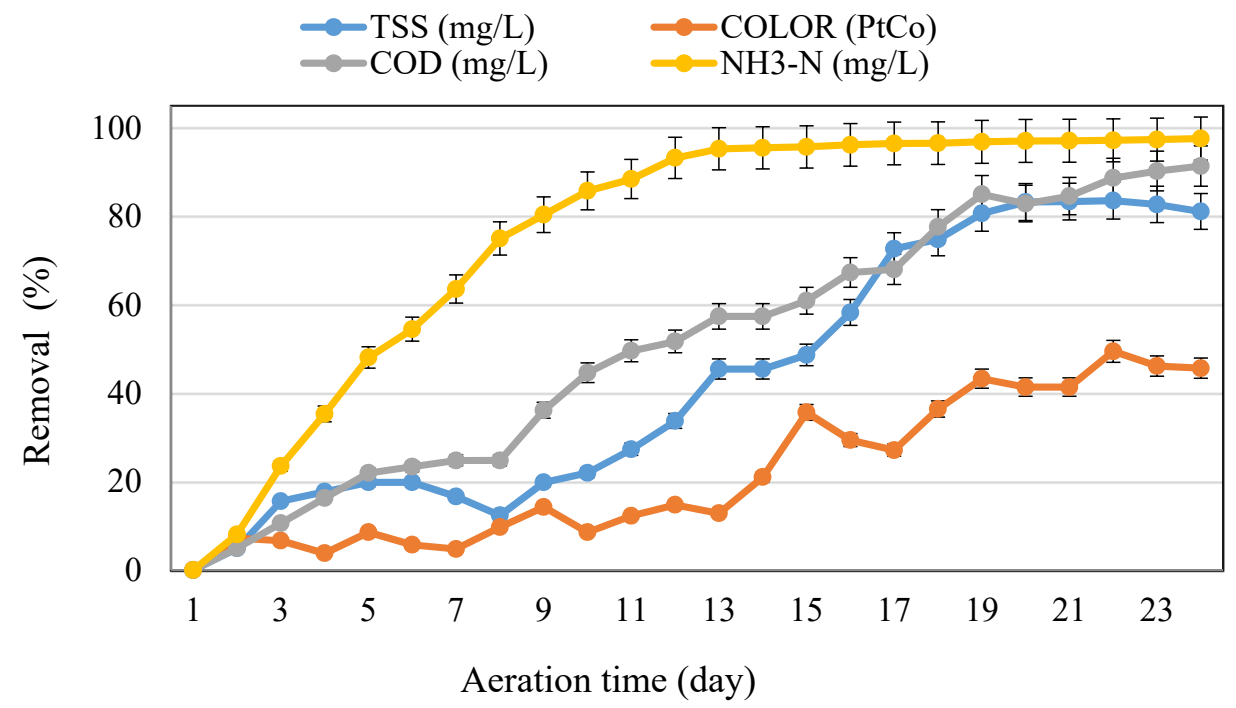

Figure 2. Effects of reaction time variation on $\mathrm{COD}$, TSS, color, and $\mathrm{NH}_{3}-\mathrm{N}$ removal efficiency (with natural pH, leachate/POME (900 mL leachate/100 mL POME), aeration power $20 \mathrm{~L} / \mathrm{min}$ ). 
3.3. Effects of Reaction Time Variation on the Removal Efficiency during the Aeration Time of Leachate/POME Treatment (Ratio 700 mL Leachate/300 mL POME)

In this stage, the effects of reaction time variation on the removal efficiency during the aeration time of leachate/POME treatment with a constant ratio (700 mL leachate/300 mL POME) were investigated for the targeted parameters under the same condition of natural $\mathrm{pH}$ and an aeration power of $20 \mathrm{~mL} / \mathrm{min}$. The results showed an increase in the removal efficiency of all targeted parameters. The maximum removal of $\mathrm{NH}_{3}-\mathrm{N}, \mathrm{COD}$, TSS, and color was $96 \%, 89 \%, 53 \%$, and $41 \%$, respectively. As shown in Figure 3, there was a higher removal efficiency for $\mathrm{NH}_{3}-\mathrm{N}$ than $\mathrm{COD}$, but color showed the lowest removal efficiency.

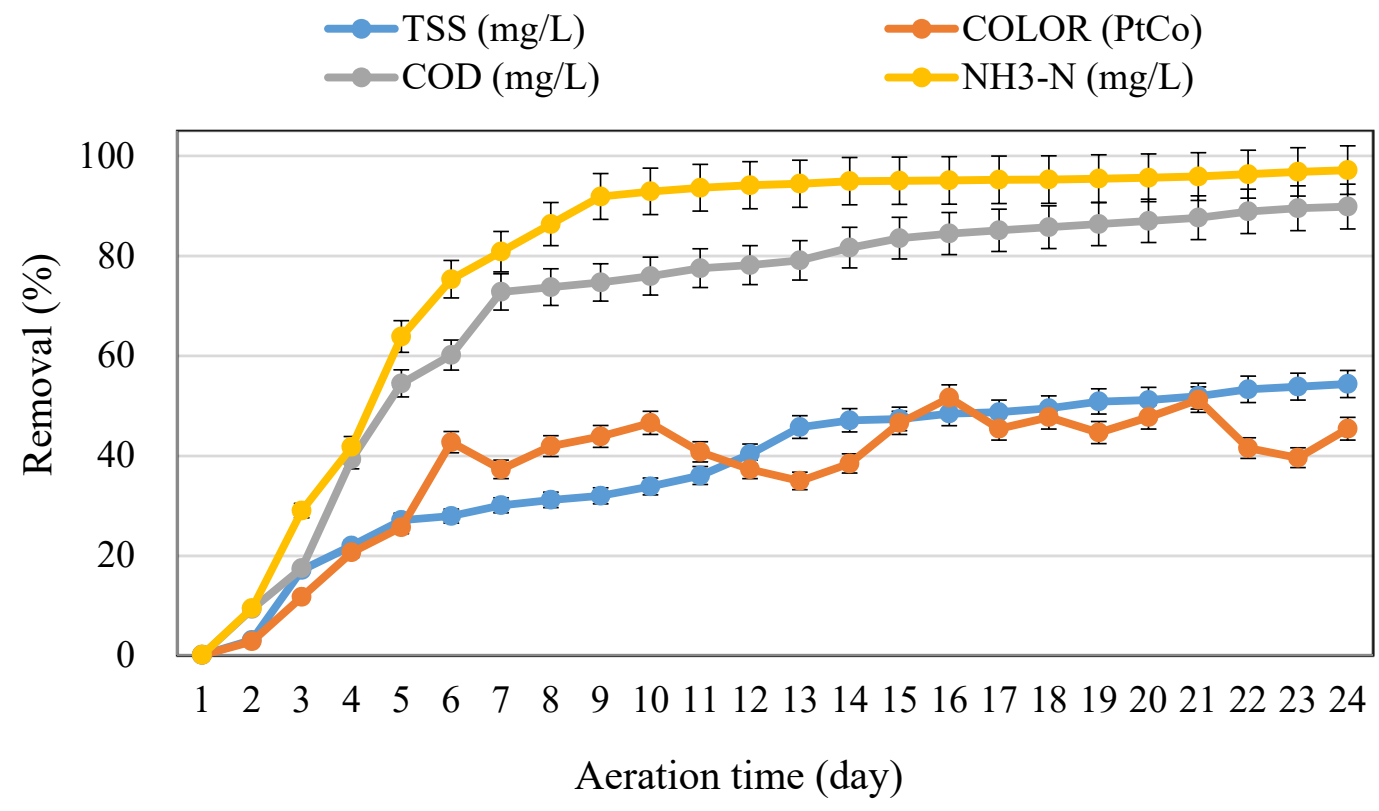

Figure 3. Effects of reaction time variation on $\mathrm{COD}$, TSS, color, and $\mathrm{NH}_{3}-\mathrm{N}$ removal efficiency (with natural $\mathrm{pH}$, leachate/POME (700 mL leachate/300 mL POME), aeration power 20L/min).

3.4. Effects of Reaction Time Variation on the Removal Efficiency during the Aeration Time of Leachate/POME Treatment (Ratio 500 mL Leachate/500 mL POME)

As shown in Figure 4, the ratio between leachate and POME was $500 \mathrm{~mL} / 500 \mathrm{~mL}$. The effect of reaction time variation on the removal efficiency during the aeration time for targeted parameters was investigated with the same conditions for the other ratios (natural $\mathrm{pH}$, aeration power $20 \mathrm{~L} / \mathrm{min}$ ). The maximum removal efficiencies for COD, TSS, color, and $\mathrm{NH}_{3}-\mathrm{N}$ were $89 \%, 21 \%, 42 \%$, and $94 \%$. The removal efficiency of $\mathrm{NH}_{3}-\mathrm{N}$ increased sharply in the first 10 days of aeration, reaching $90 \%$, and it did not demonstrate a further marked increase in removal efficiency, reaching $94 \%$ by the 24 th day. 


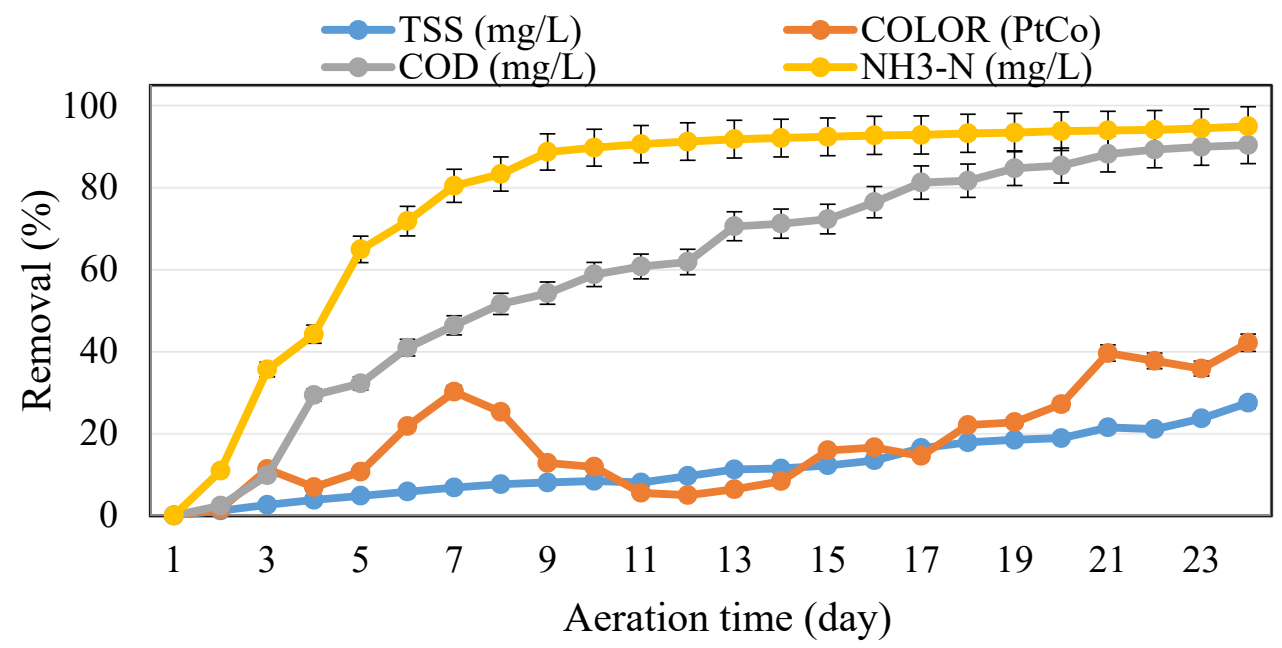

Figure 4. Effects of reaction time variation on $\mathrm{COD}$, TSS, color, and $\mathrm{NH}_{3}-\mathrm{N}$ removal efficiency (with natural $\mathrm{pH}$, leachate/POME (500 mL leachate/500 mL POME), aeration power $20 \mathrm{~L} / \mathrm{min}$ ).

\subsection{Effects of the Leachate/POME Mixing Ratio on the Leachate Aeration Process}

The treatment of leachate was implemented using POME in four ratios (leachate only, $900 \mathrm{~mL}$ leachate/100 mL POME, $700 \mathrm{~mL}$ leachate/300 mL POME, and $500 \mathrm{~mL}$ leachate $/ 500 \mathrm{~mL}$ POME) with a natural $\mathrm{pH}$ and an aeration power of $20 \mathrm{~L} / \mathrm{min}$. Accordingly, a limited removal efficiency of COD (43\%) was found when treating leachate without any POME dosages. As shown in Figure 5, adding $100 \mathrm{~mL}$, $300 \mathrm{~mL}$, and $500 \mathrm{~mL}$ of POME improved the removal efficiency of COD (COD removal of $85 \%, 88 \%$, and $88 \%$, respectively).

The results of the removal efficiencies for the targeted parameters using several dosages (leachate only, $900 \mathrm{~mL}$ leachate $/ 100 \mathrm{~mL}$ POME, $700 \mathrm{~mL}$ leachate/300 mL POME, and $500 \mathrm{~mL}$ leachate/500 mL POME) are illustrated in Figure 5. The maximum removal efficiency was $\mathrm{NH}_{3}-\mathrm{N}$, reaching $97 \%$ during the aeration process for leachate only and $900 \mathrm{~mL}$ leachate/100 $\mathrm{mL}$ POME, while the maximum removal for COD reached $88 \%(700 \mathrm{~mL}$ leachate $/ 300 \mathrm{~mL}$ POME and $500 \mathrm{~mL}$ leachate $/ 500 \mathrm{~mL}$ POME ratios). The lowest removal was $51 \%$ for TSS, followed by $52 \%$ for color for the $700 \mathrm{~mL}$ leachate/300 mL POME ratio.

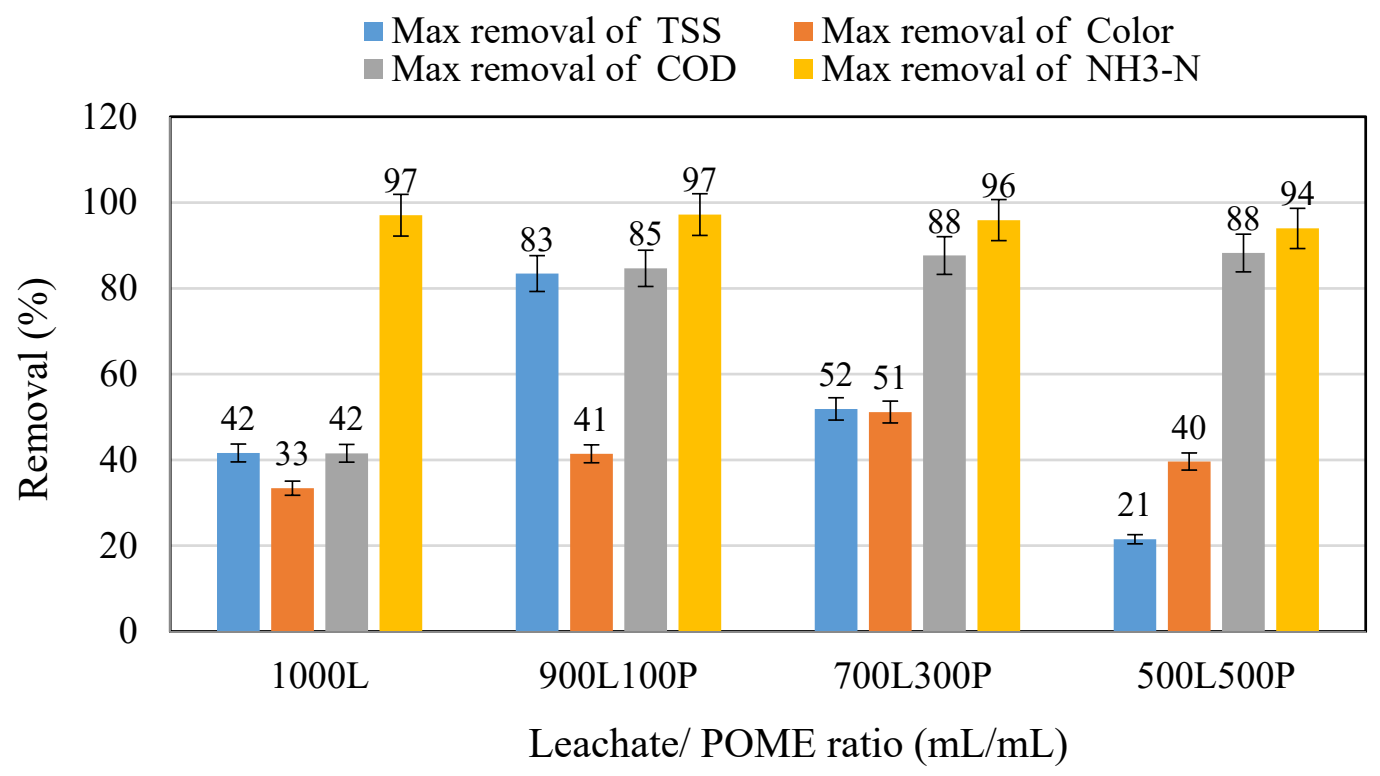

Figure 5. Effect of the leachate/POME ratios on COD, TSS, color, and $\mathrm{NH}_{3}-\mathrm{N}$ removal efficiency after 24 days of mixing aeration (with natural $\mathrm{pH}$, aeration power $20 \mathrm{~L} / \mathrm{min}$ ). 


\subsection{Analysis of Variance}

One of the key objectives of the RSM is to calculate the best value for the control variables that can maximize or minimize a response over a particular area of concern. A good-fitting model is defined to provide a proper representation of the mean response to achieve the optimum value [34]. A total of 13 experiments with different dosages (leachate/POME) and reaction times at room temperature $\left(28^{\circ} \mathrm{C}\right)$ were performed using central composite design (CCD); the outcomes were analyzed using analysis of variance (ANOVA), as shown in Table 3. The POME dosage used to treat stabilized leachate was evaluated in terms of its effectiveness in the removal of COD, TSS, color, and $\mathrm{NH}_{3}-\mathrm{N}$.

The coefficient of determination $\left(R^{2}\right)$ for COD, TSS, color, and $\mathrm{NH}_{3}-\mathrm{N}$ was $0.9927,0.8218,0.9854$, and 0.991, respectively. This mean that the models are good in Equations (6)-(9) due to the coefficient of determination being high and close to 1 (Table 4). Prior to the data analysis, the assumption of normality should be tested. The assumption of normality showed that the data roughly fit a bell-shaped curve for all responses, as presented in Figure 6.

$$
\begin{aligned}
& \text { COD removal }=+80.18+25.81 \times \mathrm{A}+8.60 \times \mathrm{B}-19.97 \times \mathrm{A}^{2}-4.00 \times \mathrm{B}^{2}-0.98 \times \mathrm{A} \times \mathrm{B} ; \\
& \text { TSS removal }=+49.93+4.32 \times \mathrm{A}+15.76 \times \mathrm{B}-6.39 \times \mathrm{A}^{2}-0.089 \times \mathrm{B}^{2}+1.02 \times \mathrm{A} \times \mathrm{B} ; \\
& \text { Color removal }=+45.74+1.35 \times \mathrm{A}+16.14 \times \mathrm{B}-17.50 \times \mathrm{A}^{2}-7.62 \times \mathrm{B}^{2}+1.20 \times \mathrm{A} \times \mathrm{B} ; \\
& \mathrm{NH}_{3}-\mathrm{N} \text { removal }=+97.24-3.05 \times \mathrm{A}+6.72 \times \mathrm{B}-1.06 \times \mathrm{A}^{2}-5.17 \times \mathrm{B}^{2}+1.92 \times \mathrm{A} \times \mathrm{B} .
\end{aligned}
$$


Table 3. Response value for different experimental conditions (POME dosages and aeration time).

\begin{tabular}{|c|c|c|c|c|c|c|c|c|c|c|c|c|c|c|}
\hline \multirow{2}{*}{ Run } & \multirow{2}{*}{$\begin{array}{c}\text { Factor A: } \\
\text { POME (mL) }\end{array}$} & \multirow{2}{*}{$\begin{array}{l}\text { Factor B: } \\
\text { Aeration } \\
\text { Time (day) }\end{array}$} & \multicolumn{3}{|c|}{ COD Removal \% } & \multicolumn{3}{|c|}{ Color Removal \% } & \multicolumn{3}{|c|}{ TSS Removal \% } & \multicolumn{3}{|c|}{$\mathrm{NH}_{3}-\mathrm{N}$ Removal \% } \\
\hline & & & Actual & Predicted & Residual & Actual & Predicted & Residual & Actual & Predicted & Residual & Actual & Predicted & Residual \\
\hline 1 & 150 & 21 & 84.5 & 84.79 & -0.29 & 51.89 & 55.1 & -3.21 & 79 & 65.53 & 13.47 & 94 & 94.26 & -0.26 \\
\hline 2 & 150 & 14 & 78.81 & 80.18 & -1.37 & 47.58 & 46.1 & 1.48 & 53.2 & 53.57 & -0.37 & 93 & 92.83 & 0.17 \\
\hline 3 & 150 & 14 & 78.31 & 80.18 & -1.87 & 44.73 & 46.1 & -1.37 & 51.3 & 53.57 & -2.27 & 93 & 92.83 & 0.17 \\
\hline 4 & 150 & 7 & 65.8 & 67.58 & -1.78 & 24.21 & 21.37 & 2.84 & 25.6 & 36.92 & -11.32 & 81 & 80.6 & 0.4 \\
\hline 5 & 150 & 14 & 78.18 & 80.18 & -2 & 47.69 & 46.1 & 1.59 & 54 & 53.57 & 0.43 & 93 & 92.83 & 0.17 \\
\hline 6 & 300 & 14 & 84.9 & 86.02 & -1.12 & 32.9 & 30.98 & 1.92 & 44 & 47.46 & -3.46 & 90 & 88.93 & 1.07 \\
\hline 7 & 0 & 14 & 33.46 & 34.4 & -0.94 & 23.44 & 25.73 & -2.29 & 36 & 30.38 & 5.62 & 94 & 94.93 & -0.93 \\
\hline 8 & 0 & 7 & 21.66 & 20.82 & 0.84 & 2.92 & 3.29 & -0.37 & 18.46 & 15.07 & 3.39 & 85 & 84.7 & 0.3 \\
\hline 9 & 300 & 7 & 75.32 & 74.39 & 0.93 & 1.5 & 3.97 & -2.47 & 37.4 & 29.47 & 7.93 & 74 & 74.7 & -0.7 \\
\hline 10 & 0 & 21 & 40.08 & 39.98 & 0.099 & 35.1 & 32.44 & 2.66 & 32 & 41 & -9 & 95 & 94.37 & 0.63 \\
\hline 11 & 300 & 21 & 89.83 & 89.64 & 0.19 & 42.81 & 42.26 & 0.55 & 56.3 & 60.76 & -4.46 & 92 & 92.37 & -0.37 \\
\hline 12 & 150 & 14 & 84.46 & 80.18 & 4.28 & 44.71 & 46.1 & -1.39 & 54.4 & 53.57 & 0.83 & 93 & 92.83 & 0.17 \\
\hline 13 & 150 & 14 & 83.22 & 80.18 & 3.04 & 46.15 & 46.1 & 0.052 & 52.8 & 53.57 & -0.77 & 92 & 92.83 & -0.83 \\
\hline
\end{tabular}


(I)

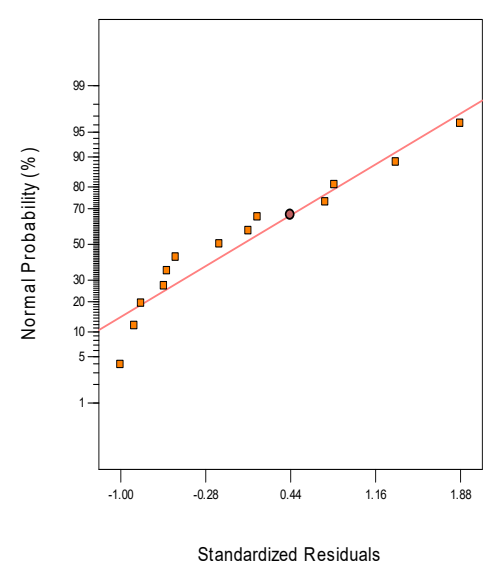

(III)

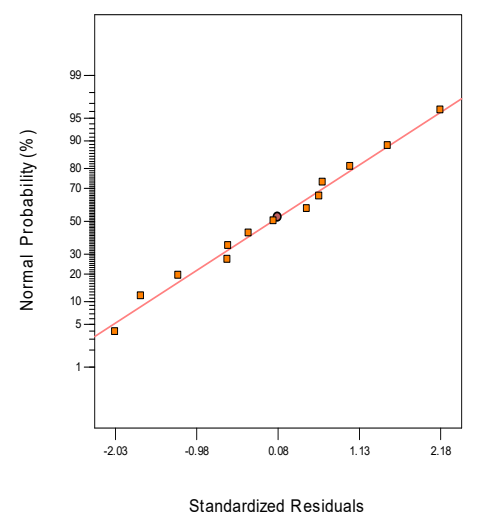

(II)

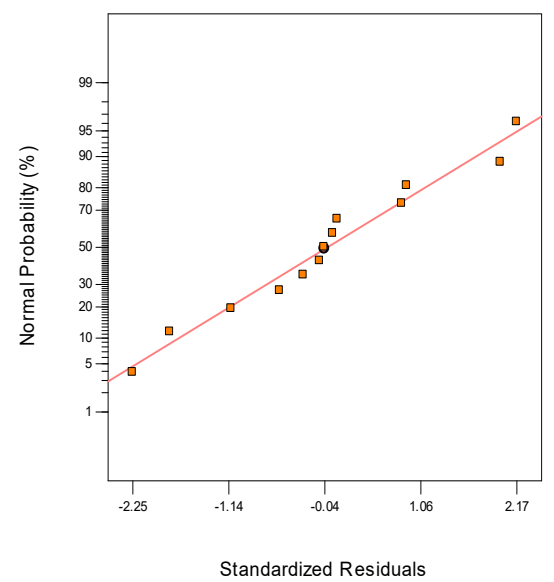

(IV)

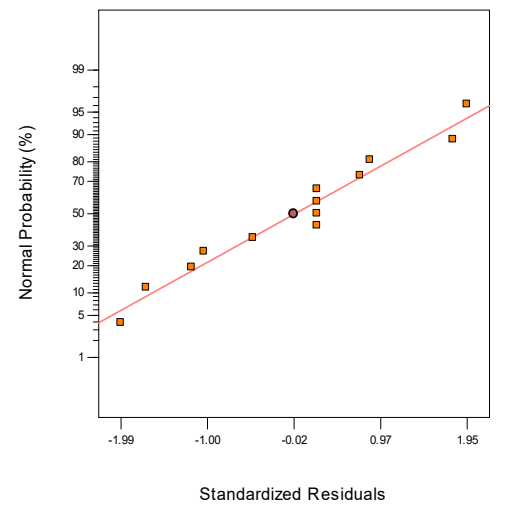

Figure 6. Normal probability plots for (I) COD, (II) TSS, (III) color, and (IV) $\mathrm{NH}_{3}-\mathrm{N}$ removal.

The two variables, POME dosage and aeration time, displayed an important impact ( $p$-value $<0.05$ ) for the linear and quadratic models on the targeted factors of $\mathrm{COD}$, color, and $\mathrm{NH}_{3}-\mathrm{N}$, as shown in Table 4 for the ANOVA results. On the other hand, a higher-order model like a third-order polynomial model or more complicated model can be used to improve the model for TSS removal.

Table 4. ANOVA for $\mathrm{COD}$, TSS, color, and $\mathrm{NH}_{3}-\mathrm{N}$ removal. A: POME dosage, B: aeration time.

\begin{tabular}{ccccccc}
\hline & Source & $\begin{array}{c}\text { Sum of } \\
\text { Squares }\end{array}$ & DF & $\begin{array}{c}\text { Mean } \\
\text { Square }\end{array}$ & F Value & Prob $>$ F \\
\cline { 2 - 6 } & Model & 5981.97 & 5 & 1196.39 & 190.7 & $<0.0001$ \\
& $\mathrm{~A}$ & 3996.42 & 1 & 3996.42 & 637 & $<0.0001$ \\
COD & $\mathrm{B}$ & 444.28 & 1 & 444.28 & 70.81 & $<0.0001$ \\
Removal & $\mathrm{A}^{2}$ & 1101.81 & 1 & 1101.81 & 175.62 & $<0.0001$ \\
$\mathbf{( \% )}$ & $\mathrm{B}^{2}$ & 44.26 & 1 & 44.26 & 7.06 & 0.0326 \\
& $\mathrm{AB}$ & 3.82 & 1 & 3.82 & 0.61 & 0.4607 \\
& Residual & 43.92 & 7 & 6.27 & & \\
& Lack of Fit & 7.85 & 3 & 2.62 & 0.29 & 0.8314 \\
& Pure Error & 36.07 & 4 & 9.02 & &
\end{tabular}

SD: $2.50, R^{2}$ : 0.9927, mean: 69.12, CV:3.62, Pred $R^{2}$ : 0.9814, Adeq Precision: 40.447. 
Table 4. Cont.

\begin{tabular}{|c|c|c|c|c|c|c|}
\hline \multirow{12}{*}{$\begin{array}{c}\text { TSS } \\
\text { Removal } \\
(\%)\end{array}$} & Source & $\begin{array}{l}\text { Sum of } \\
\text { Squares }\end{array}$ & DF & $\begin{array}{l}\text { Mean } \\
\text { Square }\end{array}$ & F Value & Prob $>$ F \\
\hline & Model & 2468.26 & 5 & 493.65 & 6.46 & 0.0148 \\
\hline & $\mathrm{A}$ & 437.59 & 1 & 437.59 & 5.72 & 0.048 \\
\hline & B & 1228.08 & 1 & 1228.08 & 16.06 & 0.0051 \\
\hline & $A^{2}$ & 592.46 & 1 & 592.46 & 7.75 & 0.0272 \\
\hline & $\mathrm{B}^{2}$ & 15.2 & 1 & 15.2 & 0.2 & 0.6691 \\
\hline & $\mathrm{AB}$ & 7.18 & 1 & 7.18 & 0.094 & 0.7681 \\
\hline & Residual & 535.16 & 7 & 76.45 & & \\
\hline & Lack of Fit & 529.33 & 3 & 176.44 & 121.02 & 0.0002 \\
\hline & Pure Error & 5.83 & 4 & 1.46 & & \\
\hline & Cor Total & 3003.43 & 12 & & & \\
\hline & SD: $8.74, R^{2}$ & 18, mean: & , CV: & Pred $R^{2}$ & 897, Adec & cision: 8.495 \\
\hline \multirow{12}{*}{$\begin{array}{c}\text { Color } \\
\text { Removal } \\
(\%)\end{array}$} & Source & $\begin{array}{l}\text { Sum of } \\
\text { Squares }\end{array}$ & DF & $\begin{array}{l}\text { Mean } \\
\text { Square }\end{array}$ & F Value & Prob $>$ F \\
\hline & Model & 3328.56 & 5 & 665.71 & 94.36 & $<0.0001$ \\
\hline & A & 41.34 & 1 & 41.34 & 5.86 & 0.046 \\
\hline & B & 1705.89 & 1 & 1705.89 & 241.8 & $<0.0001$ \\
\hline & $\mathrm{A}^{2}$ & 869.58 & 1 & 869.58 & 123.26 & $<0.0001$ \\
\hline & $\mathrm{B}^{2}$ & 170.8 & 1 & 170.8 & 24.21 & 0.0017 \\
\hline & $\mathrm{AB}$ & 20.84 & 1 & 20.84 & 2.95 & 0.1294 \\
\hline & Residual & 49.39 & 7 & 7.06 & & \\
\hline & Lack of Fit & 40.88 & 3 & 13.63 & 6.41 & 0.0523 \\
\hline & Pure Error & 8.5 & 4 & 2.13 & & \\
\hline & Cor Total & 3377.94 & 12 & & & \\
\hline & SD: $2.66, R^{2}$ & 854, mean: & $8, \mathrm{CV}$ & , Pred $R^{2}$ : & 33, Adeq & sion: 28.712 \\
\hline \multirow{12}{*}{$\begin{array}{c}\mathrm{NH}_{3}-\mathrm{N} \\
\text { Removal } \\
(\%)\end{array}$} & Source & $\begin{array}{l}\text { Sum of } \\
\text { Squares }\end{array}$ & DF & $\begin{array}{c}\text { Mean } \\
\text { Square }\end{array}$ & F Value & Prob $>$ F \\
\hline & Model & 458.76 & 5 & 91.75 & 154.36 & $<0.0001$ \\
\hline & A & 54 & 1 & 54 & 90.85 & $<0.0001$ \\
\hline & B & 280.17 & 1 & 280.17 & 471.33 & $<0.0001$ \\
\hline & $A^{2}$ & 2.22 & 1 & 2.22 & 3.73 & 0.0446 \\
\hline & $\mathrm{B}^{2}$ & 80.43 & 1 & 80.43 & 135.32 & $<0.0001$ \\
\hline & $\mathrm{AB}$ & 16 & 1 & 16 & 26.92 & 0.0013 \\
\hline & Residual & 4.16 & 7 & 0.59 & & \\
\hline & Lack of Fit & 3.36 & 3 & 1.12 & 5.6 & 0.0647 \\
\hline & Pure Error & 0.8 & 4 & 0.2 & & \\
\hline & Cor Total & 462.92 & 12 & & & \\
\hline & \multicolumn{6}{|c|}{ SD: $0.77, R^{2}: 0.991$, mean: $89.92, C V: 0.86$, Pred $R^{2}: 0.9238$, Adeq Precision: 38.623} \\
\hline
\end{tabular}

Abbreviation. DF: degrees of freedom; Cor: corrected; CV: coefficient of variation; Pred: predicted; Adeq: adequate.

In addition, the $p$-values for the interaction effect were $0.4607,0.7681$, and 0.1294 for the removal efficiency of COD, TSS, and color. In other words, the interaction effect between POME dosage and aeration time was insignificant ( $p$-value $>0.05$ ) for the removal efficiency of COD, TSS, and color. That implies that the two factors function independently. Conversely, the $p$-value (0.0013) for the interaction effect was significant for $\mathrm{NH}_{3}-\mathrm{N}$ removal efficiency. Figure 7 shows the interaction between the two (variables) factors (POME dosage and aeration time) and their behaviors in terms of removal of the targeted parameters (COD, TSS, color, and $\mathrm{NH}_{3}-\mathrm{N}$ ). The $p$-values for lack of fit were $0.8314,0.0523$, and 0.0647, which indicates that the lack of fit was insignificant ( $p$-value $>0.05$ ), which means that the model is appropriate for the removal efficiency of COD, color, and $\mathrm{NH}_{3}-\mathrm{N}$, while the $p$-value for lack of fit was significant $(p$-value $<0.05$ ) for TSS removal efficiency, indicating the model is not appropriate.

The impact of POME dosage and aeration time on the selected responses is illustrated in Figure 8. The descriptions for the behavior of each response for POME dosage and aeration time are shown as 
the surface of a three-dimensional plot for the maximization of the four targeted responses (COD, TSS, color, and $\mathrm{NH}_{3}-\mathrm{N}$ ) (Figure 8). All response plots demonstrate clear peaks, suggesting that the maximum area of impact is well known with the selected boundaries of the POME dosage and aeration time.

(I)

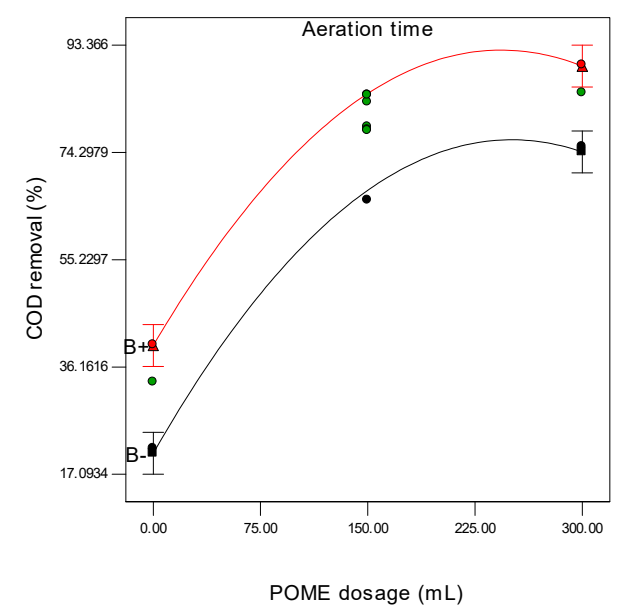

(III)

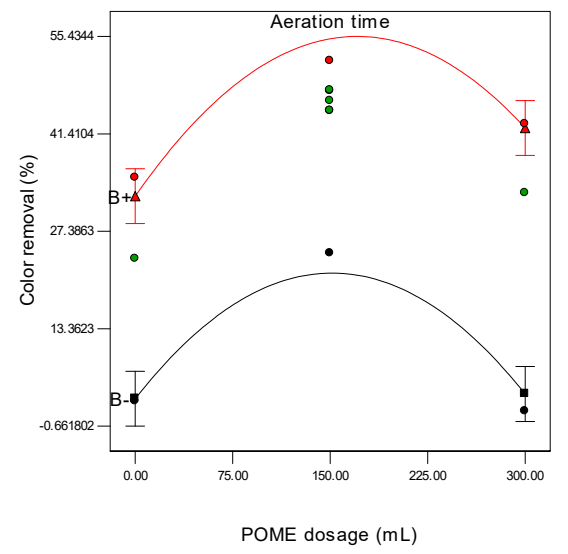

(II)

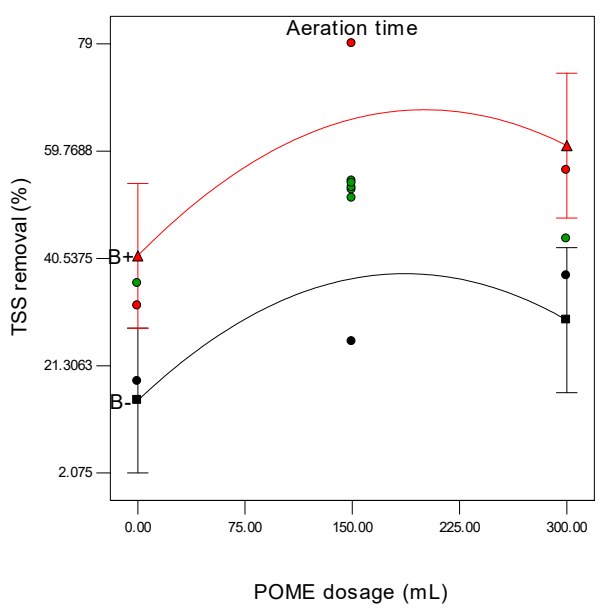

(IV)

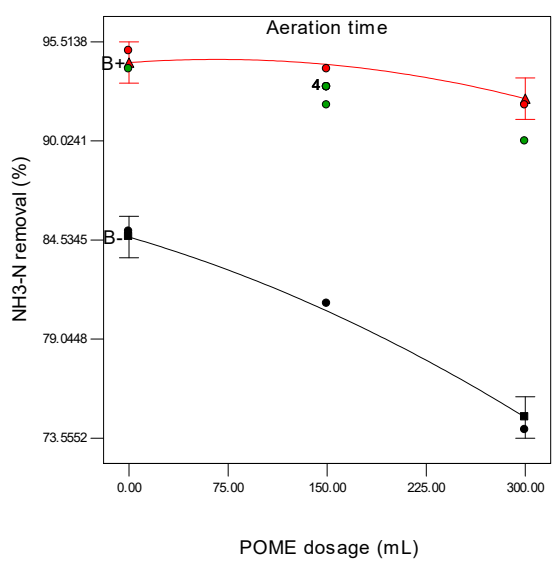

Figure 7. The impact of the POME dose combination and the aeration time for the removal of (I) COD, (II) TSS, (III) color, and (IV) $\mathrm{NH}_{3}-\mathrm{N}$. 
(I)

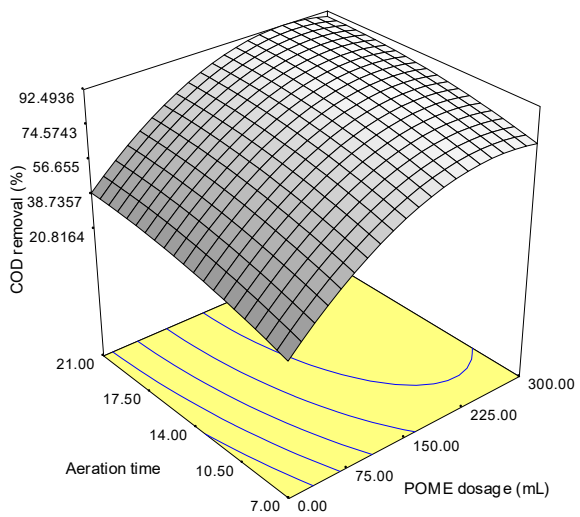

(III)

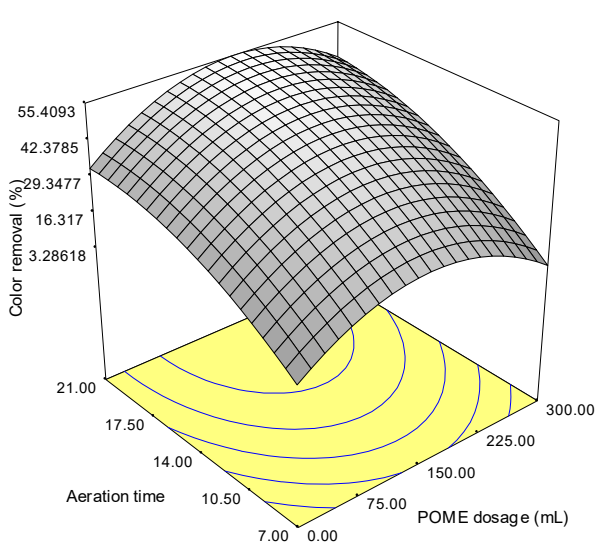

(II)

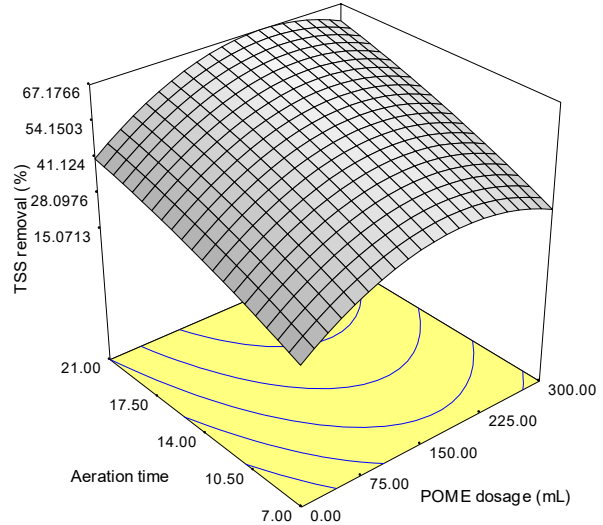

(IV)

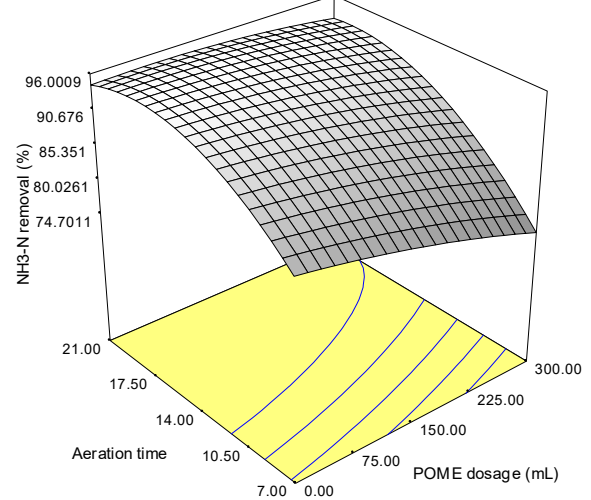

Figure 8. Response surface plot for (I) COD, (II) TSS, (III) color, and (IV) $\mathrm{NH}_{3}-\mathrm{N}$ removal.

\subsection{Optimization of Leachate Treatment Using POME}

Design-Expert 6.0.7 software offers strong tools for setting up an optimal experiment of the treatment process to identify the optimum value of removal efficiency for COD, TSS, color, and $\mathrm{NH}_{3}-\mathrm{N}$. In accordance with the approach of software optimization, the required target was within the range for each experimental condition (POME dosage and aeration time). To obtain the highest output, the responses (COD, TSS, color, and $\mathrm{NH}_{3}-\mathrm{N}$ ) were described as a maximum value. The program incorporates individual desirability into a single number and then searches on the basis of the response target to optimize this feature. The optimum conditions and respective percentage removal efficiencies were established, and the COD $(89.83 \%)$, TSS $(66.7 \%)$, color $(91.7 \%)$, and $\mathrm{NH}_{3}-\mathrm{N}(94 \%)$ removal results are illustrated in Table 5 The desirability function for these optimum conditions was recorded as 0.935 . Additional experiments under optimal conditions were performed to verify agreement with the outcome experiments from models and the experiments. The results from the laboratory experiment were $87.51 \%, 65.62 \%, 53.10 \%$, and $91.8 \%$ for the removal of COD, TSS, color, and $\mathrm{NH}_{3}-\mathrm{N}$, respectively (Table 5). There was close agreement between the removal efficiencies for all response parameters gained from the experiments and those estimated by models. These results are more efficient than the result of Banch et al. [8], who conducted tests for the same parameters except for color. Tatsi et al. [35] achieved a color removal of about $100 \%$ for partially stabilized leachate. However, the reported residuals for COD, TSS, color, and $\mathrm{NH}_{3}-\mathrm{N}$ were recorded as $430 \mathrm{mg} / \mathrm{L}, 1620 \mathrm{mg} / \mathrm{L}$, $1780 \mathrm{Pt}-\mathrm{Co}$, and $66 \mathrm{mg} / \mathrm{L}$, respectively, which are still higher than the effluent discharge limits. 
Table 5. Optimal response results from the model prediction and laboratory.

\begin{tabular}{ccccccc}
\hline POME & $\begin{array}{c}\text { Aeration } \\
\text { Time }\end{array}$ & $\begin{array}{c}\text { COD } \\
\text { Removal } \\
\mathbf{( \% )}\end{array}$ & $\begin{array}{c}\text { TSS } \\
\text { Removal } \\
\mathbf{( \% )}\end{array}$ & $\begin{array}{c}\text { Color } \\
\text { Removal } \\
\mathbf{( \% )}\end{array}$ & $\begin{array}{c}\mathbf{N H}_{3}-\mathbf{N} \\
\text { Removal } \\
\mathbf{( \% )}\end{array}$ & Desirability \\
\hline 188.38 & 21.00 & 89.83 & 67.10 & 55.19 & 93.95 & 0.935 \\
Lab experiment & 87.15 & 65.54 & 52.78 & 91.75 & \\
\hline
\end{tabular}

\subsection{Heavy Metal Analysis}

The removal efficiency of targeted heavy metals from stabilized leachate was evaluated under the achieved optimum experimental conditions, and the results are given in Table 6 . The removal efficiency for the targeted heavy metals ranged between $99.00 \%\left(\mathrm{Cd}^{2+}\right)$ and $6.85 \%\left(\mathrm{As}^{3+}\right)$. The order of residuals of heavy metals in leachate was $\mathrm{Fe}^{2+}>\mathrm{Mn}^{2+}>\mathrm{As}^{3+}>\mathrm{Zn}^{2+}>\mathrm{Cr}^{2+}>\mathrm{Cu}^{2+}>\mathrm{Co}^{2+}>\mathrm{Pb}^{+}>\mathrm{Cd}^{2+}$ from highest to lowest concentration. The heavy metal residuals were 1856, 31.72, 16.15, 10.76, 2.80, 1.28, 0.53, 0.28 , and $0.23 \mu \mathrm{g} / \mathrm{L}$ for $\mathrm{Fe}^{2+}, \mathrm{Mn}^{2+}, \mathrm{As}^{3+}, \mathrm{Zn}^{2+}, \mathrm{Cr}^{2+}, \mathrm{Cu}^{2+}, \mathrm{Co}^{2+}, \mathrm{Pb}^{+}$, and $\mathrm{Cd}^{2+}$, respectively, while the removal efficiency was $90.73 \%, 34.75 \%, 6.85 \%, 96.16 \%, 93.78 \%, 96.95 \%, 95.24 \%, 93.30 \%$, and $99.00 \%$ respectively. Only the concentration of $\mathrm{Mn}^{2+}$ existed out of the limits, while the other targeted heavy metals were within the limits. The removal of heavy metals is attributed to the high level of suspended solids and metal complexes in POME which may act as a natural coagulant. The suspended solids and metal complexes improve the charged exchange and accelerated the adsorption and deposition of dissolved heavy metals in wastewater [36-40]. This study showed more efficient removal than Banch et al. [8] for $\mathrm{Fe}^{2+}, \mathrm{As}^{3+}, \mathrm{Zn}^{2+}, \mathrm{Cr}^{2+}, \mathrm{Cu}^{2+}, \mathrm{Co}^{2+}$, and $\mathrm{Cd}^{2+}$.

Table 6. Effect of the POME dosage and aeration time on heavy metal removal (POME dosage 188.32, aeration time 21 days).

\begin{tabular}{cccc}
\hline Heavy Metals & $\begin{array}{c}\text { Initial Concentration } \\
\text { in Leachate }\end{array}$ & $\begin{array}{c}\text { Residual after } \\
\text { Treatment Process }\end{array}$ & Removal (\%) \\
\hline $\mathrm{Fe}^{2+}(\mu \mathrm{g} / \mathrm{L})$ & $20.04 \pm 7.11$ & $1856 \pm 0.57$ & 90.73 \\
$\mathrm{Zn}^{2+}(\mu \mathrm{g} / \mathrm{L})$ & $280.00 \pm 19.63$ & $10.76 \pm 2.10$ & 96.16 \\
$\mathrm{Cu}^{2+}(\mu \mathrm{g} / \mathrm{L})$ & $41.91 \pm 20.19$ & $1.28 \pm 0.64$ & 96.95 \\
$\mathrm{Cr}^{2+}(\mu \mathrm{g} / \mathrm{L})$ & $45.11 \pm 12.81$ & $2.80 \pm 1.01$ & 93.78 \\
$\mathrm{Cd}^{2+}(\mu \mathrm{g} / \mathrm{L})$ & $22.62 \pm 3.51$ & $0.23 \pm 0.20$ & 99.00 \\
$\mathrm{~Pb}^{+}(\mu \mathrm{g} / \mathrm{L})$ & $4.18 \pm 2.91$ & $0.28 \pm 0.12$ & 93.30 \\
$\mathrm{As}^{3+}(\mu \mathrm{g} / \mathrm{L})$ & $17.34 \pm 4.29$ & $16.15 \pm 2.37$ & 6.85 \\
$\mathrm{Co}^{2+}(\mu \mathrm{g} / \mathrm{L})$ & $11.05 \pm 5.54$ & $0.53 \pm 0.39$ & 95.24 \\
$\mathrm{Mn}^{2+}(\mu \mathrm{g} / \mathrm{L})$ & $48.61 \pm 14.99$ & $31.72 \pm 7.16$ & 34.75 \\
\hline
\end{tabular}

\section{Conclusions}

The current work evaluated the use of POME as an agro-industrial waste for landfill leachate treatment. Biological treatment using an aeration process for different mixing ratios between leachate and POME was performed. The optimization of the removal efficiencies for COD, TSS, color, and $\mathrm{NH}_{3}-\mathrm{N}$ for the aeration treatment process of old leachate was investigated in this study. The optimum operational conditions were obtained at $188.32 \mathrm{~mL}$ of POME added to $1 \mathrm{~L}$ of leachate for 21 days of aeration time. The respective percentage removal efficiencies were $89.83 \%, 66.7 \%, 91.7 \%$, and $94 \%$ for COD, TSS, color, and $\mathrm{NH}_{3}-\mathrm{N}$. Moreover, the treatment process reported an efficient removal of some heavy metals from landfill leachate. The results revealed that POME-based agricultural waste can be effectively used for organic removal from stabilized leachate.

Author Contributions: Formal analysis, T.J.H.B.; writing-original draft preparation, T.J.H.B.; writing-review and editing, M.M.H., S.S.A.A., A.F.M.A., and M.H.; supervision, M.M.H. and S.S.A.A.; funding acquisition, M.M.H. All authors read and agreed to the published version of the manuscript.

Funding: This research was partly funded by UKM research grants (DIP-2019-001 and MI-2020-005). 
Acknowledgments: Marlia M. Hanafiah was supported by the Ministry of Education Malaysia (FRGS/1/2018/WAB05/UKM/02/2) and a UKM research grant (DIP-2019-001).

Conflicts of Interest: The authors declare no conflict of interest.

\section{References}

1. Gu, Z.; Chen, W.; Li, Q.; Zhang, A. Treatment of semi-aerobic aged-refuse biofilter effluent from treating landfill leachate with the Fenton method. Process. Saf. Environ. Prot. 2020, 133, 32-40. [CrossRef]

2. Guvenc, S.Y. Optimization of COD removal from leachate nanofiltration concentrate using $\mathrm{H}_{2} \mathrm{O}_{2} / \mathrm{Fe}^{+2} /$ heat-activated persulfate oxidation process. Process. Saf. Environ. Prot. 2019, 126, 7-17. [CrossRef]

3. Renou, S.; Givaudan, J.; Poulain, S.; Dirassouyan, F.; Moulin, P. Landfill leachate treatment: Review and opportunity. J. Hazard. Mater. 2008, 150, 468-493. [CrossRef] [PubMed]

4. Shalini, S.S.; Joseph, K.J. Nitrogen management in landfill leachate: Application of SHARON, ANAMMOX and combined SHARON-ANAMMOX process. Waste Manag. 2012, 32, 2385-2400. [CrossRef] [PubMed]

5. Abdulhasan, M.J.; Hanafiah, M.M.; Satchet, M.S.; Abdulaali, H.S.; Toriman, M.E.; AlRaad, A.A. Combining GIS, fuzzy logic and AHP models for solid waste disposal site selection in Nasiriyah, Iraq. Appl. Ecol. Environ. Res. 2019, 17, 6701-6722. [CrossRef]

6. Adhikari, B.; Dahal, K.R.; Khanal, S.N. A review of factors affecting the composition of municipal solid waste landfill leachate. Int. J. Eng. Sci. Innov. Technol. 2014, 3, 272-281.

7. Hermosilla, D.; Cortijo, M.; Huang, C. Optimizing the treatment of landfill leachate by conventional Fenton and photo-Fenton processes. Sci. Total Environ. 2009, 407, 3473-3481. [CrossRef]

8. Banch, T.J.; Hanafiah, M.M.; Alkarkhi, A.F.; Salem, A.M. Factorial design and optimization of landfill leachate treatment using tannin-based natural coagulant. Polymers 2019, 11, 1349. [CrossRef]

9. Banch, T.J.; Hanafiah, M.M.; Alkarkhi, A.F.; Salem, A.M. Statistical evaluation of landfill leachate system and its impact on groundwater and surface water in Malaysia. Sains Malays. 2019, 48, 2391-2403. [CrossRef]

10. Banch, T.J.; Hanafiah, M.M.; Alkarkhi, A.F.; Salem, A.M.; Nizam, N.U. Evaluation of different treatment processes for landfill leachate using low-cost agro-industrial materials. Processes 2020, 8, 111. [CrossRef]

11. Maslahati Roudi, A.; Chelliapan, S.; Wan Mohtar, W.; Kamyab, H. Prediction and optimization of the fenton process for the treatment of landfill leachate using an artificial neural network. Water 2018, 10, 595. [CrossRef]

12. Amr, S.S.A.; Aziz, H.A.; Adlan, M.N.J. Optimization of stabilized leachate treatment using ozone/persulfate in the advanced oxidation process. Waste Manag. 2013, 33, 1434-1441. [CrossRef] [PubMed]

13. Rada, E.; Istrate, I.; Ragazzi, M.; Andreottola, G.; Torretta, V. Analysis of electro-oxidation suitability for landfill leachate treatment through an experimental study. Sustainability 2013, 5, 3960-3975. [CrossRef]

14. Bashir, M.J.; Aziz, H.A.; Amr, S.S.A.; Sethupathi, S.A.P.; Ng, C.A.; Lim, J. The competency of various applied strategies in treating tropical municipal landfill leachate. Desalin. Water Treat. 2015, 54, 2382-2395. [CrossRef]

15. Mojiri, A. Review on membrane bioreactor, ion exchange and adsorption methods for landfill leachate treatment. Aust. J. Basic Appl. Sci. 2011, 5, 1365-1370.

16. Mussa, Z.H.; Othman, M.R.; Abdullah, M.P. Electrochemical oxidation of landfill leachate: Investigation of operational parameters and kinetics using graphite-PVC composite electrode as anode. J. Braz. Chem. Soc. 2015, 26, 939-948. [CrossRef]

17. Aziz, N.I.H.A.; Hanafiah, M.M. Life cycle analysis of biogas production from anaerobic digestion of palm oil mill effluent. Renew. Energy 2020, 145, 847-857. [CrossRef]

18. Aziz, N.I.H.A.; Hanafiah, M.M.; Ali, M.Y. Sustainable biogas production from agrowaste and effluents-A promising step for small-scale industry income. Renew. Energy 2019, 132, 363-369. [CrossRef]

19. Ma, W.; Han, Y.; Ma, W.; Han, H.; Zhu, H.; Xu, C.; Li, K.; Wang, D. Enhanced nitrogen removal from coal gasification wastewater by simultaneous nitrification and denitrification (SND) in an oxygen-limited aeration sequencing batch biofilm reactor. Bioresour. Technol. 2017, 244, 84-91. [CrossRef]

20. Aziz, N.I.H.A.; Hanafiah, M.M.; Gheewala, S. A review on life cycle assessment of biogas production: Challenges and future perspectives in Malaysia. Biomass Bioenergy 2019, 122, 361-374. [CrossRef]

21. Hao, Y.J.; Ji, M.; Chen, Y.X.; Wu, W.X.; Hao, Y.J.; Zhang, S.G.; Liu, H.Q. The pathway of in-situ ammonium removal from aerated municipal solid waste bioreactor: Nitrification/denitrification or air stripping? Waste Manag. Res. 2010, 28, 1057-1064. [CrossRef] [PubMed] 
22. Daud, Z.; Awang, H. Integrated Leachate Treatment Technology. In Waste Management: Concepts, Methodologies, Tools, and Applications; IGI Global: Hershey, PA, USA, 2020; pp. 204-220.

23. Jagaba, A.H.; Latiff, A.A.; Latiff, A.; Umaru, I.; Abubakar, S.; Lawal, I. Treatment of Palm Oil Mill Effluent (POME) by Coagulation-Flocculation using Different Natural and Chemical Coagulants: A Review. IOSR J. Mech. Civ. Eng. 2016, 13, 67-75.

24. Mohamed, A.F.; Yaacob, W.W.; Taha, M.R.; Samsudin, A.R. Groundwater and soil vulnerability in the Langat Basin Malaysia. Eur. J. Sci. Res. 2009, 27, 628-635.

25. Hanafiah, M.M.; Yussof, M.K.M.; Hasan, M.; AbdulHasan, M.J.; Toriman, M.E. Water quality assessment of Tekala River, Selangor, Malaysia. Appl. Ecol. Environ. Res. 2018, 16, 5157-5174. [CrossRef]

26. Thaldiri, N.H.; Hanafiah, M.M.; Halim, A.A. Effect of modified micro-sand, poly-aluminium chloride and cationic polymer on coagulation-flocculation process of landfill leachate. Environ. Ecosyst. Sci. 2017, 1, 17-19. [CrossRef]

27. Banch, T.J.H.; Hanafiah, M.M.; Amr, S.S.A.; Ashraf, M.A. Characterization of leachate from Ampar Tenang closed landfill site, Selangor, Malaysia. AIP Conf. Proc. 2019, 2111, 060009.

28. Yusoff, I.; Alias, Y.; Yusof, M.; Ashraf, M.A. Assessment of pollutants migration at Ampar Tenang landfill site, Selangor, Malaysia. Sci. Asia 2013, 39, 392-409. [CrossRef]

29. US Environmental Protection Agency. Effluent Limitations Guidelines, Pretreatment Standards and New Source Performance Standards for the Landfills Point Source Category. 2000. Available online: https://www.federalregister.gov/documents/2000/01/19/00--1037/effluent-limitations-guidelinespretreatment-standards-and-new-sourceperformance-standards-for-the (accessed on 7 January 2020).

30. Environmental Quality (Control of Pollution from Solid Waste Transfer Station and Landfill) Regulations Malaysia; FAO: Rome, Italy, 2009.

31. APHA-American Public Health Association. 2540 Solids, 2540-D Total Suspended Solids Dried at $103-105^{\circ} \mathrm{C}$; Alpha Analytical, Inc.: Holmes, PA, USA, 2012.

32. US Environmental Protection Agency. Standard Methods for the Examination of Water and Wastewater; American Public Health Association: Washington, DC, USA, 2005; Volume 2.

33. Feron, P. (Ed.) Absorption-Based Post-Combustion Capture of Carbon Dioxide; Woodhead Publishing: Cambridge, UK, 2016.

34. Bonmatı, A.; Flotats, X. Air stripping of ammonia from pig slurry: Characterisation and feasibility as a pre-or post-treatment to mesophilic anaerobic digestion. Waste Manag. 2003, 23, 261-272. [CrossRef]

35. Tatsi, A.A.; Zouboulis, A.I.; Matis, K.A.; Samaras, P. Coagulation-flocculation pretreatment of sanitary landfill leachates. Chemosphere 2003, 53, 737-744. [CrossRef]

36. Ashraf, M.A.; Balkhair, K.S.; Chowdhury, A.J.K.; Hanafiah, M.M. Treatment of Taman Beringin landfill leachate using the column technique. Desalin. Water Treat. 2019, 149, 370-387. [CrossRef]

37. Manikam, M.K.; Halim, A.A.; Hanafiah, M.M.; Krishnamoorthy, R.R. Removal of ammonia nitrogen, nitrate, phosphorus and COD from sewage wastewater using palm oil boiler ash composite adsorbent. Desalin. Water Treat. 2019, 149, 23-30. [CrossRef]

38. Hanafiah, M.M.; Zainuddin, M.F.; Nizam, N.U.M.; Rasool, A. Phytoremediation of Aluminium and Iron from Industrial Wastewater Using Ipomoea aquatica and Centella asiatica. Appl. Sci. 2020, 10, 3064. [CrossRef]

39. Nizam, N.U.M.; Hanafiah, M.M.; Noor, I.M.; Karim, H.I.A. Efficiency of five selected aquatic plants in phytoremediation of aquaculture wastewater. Appl. Sci. 2020, 10, 1-11.

40. Asman, N.S.; Halim, A.A.; Hanafiah, M.M.; Ariffin, F.D. Determination of rainwater quality from rainwater harvesting system at Ungku Omar College, UKM Bangi. Sains Malays. 2017, 46, 1211-1219. [CrossRef]

(C) 2020 by the authors. Licensee MDPI, Basel, Switzerland. This article is an open access article distributed under the terms and conditions of the Creative Commons Attribution (CC BY) license (http://creativecommons.org/licenses/by/4.0/). 